\title{
Study on teaching practices based on modern apprenticeship
}

\author{
She Minghong ${ }^{1, a}$, Yang Hongbing ${ }^{2, b}$ and Tang Jiyong 3 ,a \\ ${ }^{1}$ Computer College, Chongqing College of Electronic Engineering; Chongqing Shapingba,China , \\ 401331 , mh_she@126.com \\ ${ }^{2}$ Sichuan Minzu College; Sichuan Kangding 626001,China

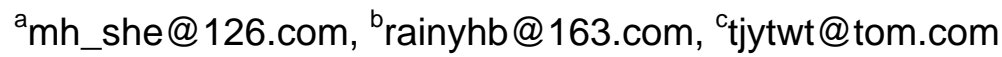

Keywords: modern apprenticeship; teaching practice; research.

Abstract. Aiming at the problem that the talent training of higher vocational colleges in our country cannot meet the social demand, the new mode of modern apprenticeship has solved this problem to a certain degree. The modern apprenticeship popularized in higher vocational colleges can strengthen the exchange between enterprises and institutions, improve students' ability to combine theory with practice, which is of great benefit to students' future development. This paper conducts relative research and practice based on modern apprenticeship, hoping to promote the modern apprenticeship in China' s higher vocational colleges to play a greater role in popularization.

\section{Introduction}

In higher vocational colleges, the modern apprenticeship attaches great importance to cultivate students' technical ability and also to the key problem about how to combine the students' knowledge with practice. Modern apprenticeship is a kind of talent training mode which is developed on the basis of the traditional apprenticeship system. Through strengthening the cooperation between higher vocational colleges and enterprises, it promotes students' ability to combine theory with practice, improves students' social competency and helps to achieve the life goal that they can obtain employment soon after graduation to the maximum extent.

\section{Talent training status in Chinese higher vocational colleges}

In Chinese higher vocational colleges, a large number of graduates are faced with employment difficulties. Teaching effect of technical talents oriented towards market demand in higher vocational colleges is not satisfying. There are three reasons for this. First, daily teaching activities of higher vocational colleges focus too much on theories while ignoring practices. The "Instructor-Engineer" type teachers are lacking, thus resulting in poor practical abilities of students. Second, many higher vocational colleges cannot provide practical training sites for students. Knowledge acquired by students can hardly serve their practices. Their social competitiveness is limited. At last, due to the influence of the above two aspects, students in higher vocational colleges lack a clear life goal. They drift along, thus mismatching their professional qualities and techniques with social demands. All these reasons result in their unemployment. If the problem is left unsolved, Chinese higher vocational education will lose its value. Table 1 shows statistics of the employment status of computer majors graduating from a higher vocational college in China in 2015 [1].

Table 1Statistics of employment status in a higher vocational college in 2015

\begin{tabular}{|c|c|c|c|}
\hline \multirow{2}{*}{$\begin{array}{l}\text { Employment } \\
\text { status }\end{array}$} & \multirow{2}{*}{$\begin{array}{l}\text { Computer-related } \\
\text { jobs }\end{array}$} & \multirow{2}{*}{$\begin{array}{l}\text { Oth } \\
\text { ers }\end{array}$} & \multirow{2}{*}{$\begin{array}{l}\text { Unemploym } \\
\text { ent }\end{array}$} \\
\hline & & & \\
\hline Number & 988 & 455 & 357 \\
\hline \multirow[t]{2}{*}{ Percentage } & $54.89 \%$ & 25.2 & 19.83 \\
\hline & & $8 \%$ & \\
\hline
\end{tabular}




\section{Problems existing in talent training of Chinese higher vocational colleges}

Unconformity between talent training objective and social demands. In many Chinese higher vocational colleges, that the technical talents cannot meet corporate demands has been a common phenomenon, which directly results in students' employment difficulties and enterprises' recruitment difficulties. The root reason is that Chinese higher vocational colleges fail to do a thorough survey of social demands and sticks to the stereotyped teaching model. Without solving these problems, the enrolment rate of Chinese higher vocational colleges will keep dropping, which might even exert a negative influence on Chinese economic development [2].

Lack of the "Instructor-Engineer" type faculty team. Higher vocational colleges are expected to commit to foster students with specific techniques. However, currently, in many higher vocational colleges, most teachers have adequate theoretical knowledge but lack corresponding practices. Under the teaching mode, students' potential to put knowledge acquired into practices will be impaired. Worse still, it might influence students' future employment. In recent years, the Chinese government has called upon higher vocational colleges to build an "Instructor-Engineer" type faculty team so as to realize the combination of theoretical knowledge and practices and fundamentally improve students' professional technical and practical skills. Despite that, “Instructor-Engineer” type teachers are still insufficient in China. Due to that, the faculty team in many Chinese higher vocational colleges still focuses more on theories while ignoring practices. Under the teaching mode, the teaching effects are far from being satisfying. Table 2 shows the proportion of "Instructor-Engineer" type teachers and ordinary teachers [3].

Table 2 Proportion of ordinary teachers and "Instructor-Engineer" type teachers

\begin{tabular}{llc}
\hline Faculty type & Ordinary teachers & $\begin{array}{c}\text { "Instructor-Engineer" } \\
\text { type teachers }\end{array}$ \\
\hline Number & 78 & 8 \\
Proportion & $90.69 \%$ & $9.31 \%$ \\
\hline
\end{tabular}

Backwardness of the teaching mode and the curriculum system

In China, many higher vocational colleges have a unique teaching mode and curriculum system of their own. However, both their teaching mode and curriculum system are not feasible and scientific in practices. During the design process, they ignore the employment-oriented teaching idea but seeking the teaching curriculum setting for undergraduate colleges. Such phenomena impede students' learning of professional skills and knowledge and seriously influence their employment after graduation. Without professional skills and knowledge, they are uncompetitive in the job market.

Establishment of a new-type talent training mode based on the modern apprenticeship

The introduction of a new-type talent training mode based on modern apprenticeship can contribute to integration of learning and work of students, and improve their ability to put their professional knowledge into practices. In order to build a talent training mode based on modern apprenticeship, higher vocational colleges should innovate themselves through four stages [4]:

1) Stage 1: Launch the "Instructor-Engineer" system and combine basic curriculum and extracurricular tutoring

The first three semesters of higher vocational colleges belong to the first stage of the talent training mode based on modern apprenticeship. In the first stage, students learn basic theoretical knowledge from teachers. According to students' interest and academic performance, teachers will design about five core courses for them. Students are expected to focus on learning the five core courses chosen by their teachers. Besides, higher vocational colleges should arrange extracurricular tutors to give employment counseling to students so as to help students clarify their career goal.

2) Stage 2: Build an in-campus practical training base to closely connect students' theoretical knowledge and training of practical abilities

The fourth semester of higher vocational colleges belongs to the second stage of the talent training mode based on modern apprenticeship. In the stage, students can try to put their knowledge acquired into practices so as to foster their practical abilities and lay a solid foundation for the following stage. 
3) Stage 3: Take substituted post exercitation in enterprises and achieve smooth transition from in-campus practices to workplace

After the end of the second stage, students can step in the third stage of the talent training mode based on modern apprenticeship. This is a core stage. During the stage, students in higher vocational colleges might take substituted post exercitation in enterprises. Under the leadership of senior staff in enterprises, they work while learning. This is a specific demonstration of modern apprenticeship, and can well ground students' employment skills [5].

4) Stage 4: Take internships in enterprises and get offers instantly after graduation

After undergoing substituted post exercitation, students enter the last stage of the talent training mode based on modern apprenticeship. The stage generally starts in the last semester of students in higher vocational colleges. Students take specific positions in enterprises, and work as an intern without step-by-step guidance of senior staff. During the stage, students and enterprises can choose each other, and students can get offers instantly after graduation.

\section{Conclusions}

China's higher vocational colleges are faced with various teaching problems, and the talent training mode based on modern apprenticeship can well solve these problems. Therefore, it is imperative for Chinese higher vocational colleges to put the talent training mode based on modern apprenticeship into place. After proving its feasibility, higher vocational colleges can further promote it to solve the shortage of technical talents facing Chinese society and boost China's economic development.

\section{Acknowledgements}

This work was supported by Chongqing Municipal Higher Education Teaching Reform of key projects, Project Name: Research and Construction of Electronic Information to Professional Practice Teaching Evaluation System Project Number: 142059, Chongqing Education Science and planning issues, project name: Impact Factors and Countermeasures Electronic Information of Higher Vocational Students' professional identity. Project number: 2014-GX-137, and Chongqing College of Electronic Engineering Education Education Reform Project Project Name: Research and Practice relying on skills competition Innovation Network Technology Practice Teaching System Project Number: 201401.

\section{References}

[1] ZHAO Yousheng, WANG Jun, ZHANG Qingling, et al. Exploration of practices of modern apprenticeship in higher vocational colleges-Taking Changchun Vocational Institute Of Technology as an example [J]. Vocational and Technical Education, 2014, 11: 72-74.

[2] GAO Kuifen. On the current problems and solutions of modern apprenticeship in higher vocational colleges-from the first modern apprenticeship teaching conference [J]. Journal of Hennan Institute of Science and Technology (Social Sciences Edition), 2014, 06: 5-9.

[3] ZHANG Qingling. Exploration on practice of modern apprenticeship in mechatronics technology specialty of higher vocational education [J]. Vocational and Technical Education, 2014, 14: 27-29. [4] XIONG Yu, REN Juanping, HUANG Hao, et al. Exploration and practices of talent training mode under the modern apprenticeship in higher vocational colleges [J]. Career Horizon, 2014, 09: 85-87+90.

[5]TIAN Ju, LEI Shuguang \& ZHENG Xiaochun. Research into construction of the extracurricular practical teaching base according to the modern apprenticeship system [J]. Management \& Technology of SME, 2014, 11: 229. 